\title{
EKSPOSISI MATIUS 2 AYAT 15
}

Dalam Perjanjian Baru, sering ditemukan bahwa penulis kitab mengutip ayat-ayat dari Perjanjian Lama. Misalnya dalam Matius 2:5-6: Mereka berkata kepadanya: "Di Betlehem di tanah Yudea, karena demikianlah ada tertulis dalam kitab nabi: Dan engkau Betlehem, tanah Yehuda, engkau sekali-kali bukanlah yang terkecil di antara mereka yang memerintah Yehuda, karena dari padamulah akan bangkit seorang pemimpin, yang akan menggembalakan umat-Ku Israel."; Matius 4:4, Tetapi Yesus menjawab: "Ada tertulis: Manusia hidup bukan dari roti saja, tetapi dari setiap firman yang keluar dari mulut Allah."; Matius 21:13, dan berkata kepada mereka: "Ada tertulis: Rumah-Ku akan disebut rumah doa. Tetapi kamu menjadikannya sarang penyamun."; Matius 26:24, Anak Manusia memang akan pergi sesuai dengan yang ada tertulis tentang Dia, akan tetapi celakalah orang yang olehnya Anak Manusia itu diserahkan. Adalah lebih baik bagi orang itu sekiranya ia tidak dilahirkan."; Matius 2:15, dan tinggal di sana hingga Herodes mati. Hal itu terjadi supaya genaplah yang difirmankan Tuhan oleh nabi: "Dari Mesir Kupanggil Anak-Ku."; dan masih banyak lagi ayat-ayat yang lain dalam perjanjian baru yang mengutip langsung dari Perjanjian Lama.

Menarik untuk mempelajari kutipan-kutipan penulis Perjanjian Baru tersebut. Pertanyaan yang sering muncul ialah bahwa apakah kutipan tersebut memang ditujukan kepada pokok yang sedang dibahas, atau apakah penulis Perjanjian Baru hanya ingin mengatakan bahwa betapa pentingnya Perjanjian Lama itu?

Jika memperhatikan penulisan Alkitab secara khusus tulisan Perjanjian Baru yang langsung mengutip dari Perjanjian Lama maka kadang pembaca sulit mengerti secara jelas apa maksud dari pengutipan tersebut.1 Oleh karena itu, maka sangat penting mempelajari kutipan-kutipan itu dan latar belakang serta sejarah penulisan Alkitab termasuk pengutipannya.

Dalam makalah ini, penulis mencoba menggambarkan tentang Matius 2:15, secara khusus kutipan "Dari Mesir Kupanggil Anak-Ku.”

\section{Penjelasan Matius 2:15}

Pada bagian ini, penulis akan menjelaskan tentang apa makna di balik kutipan dari Matius tersebut.

1 Marsi Bombongan Rantesalu, DOKTRIN KERAJAAN SERIBU TAHUN BERDASARKAN KITAB WAHYU, preprint (AgriXiv, October 14, 2019), accessed January 21, 2020, https://osf.io/cpvjr. 


\section{Tidak Seorangpun yang Dapat Menggagalkan Rencana Allah}

Karya penyelamatan Allah ternyata mendapat respons atau tanggapan yang berbeda-beda.2 Ada yang menanggapi dengan sukacita seperti Maria, para Majus, gembala-gembala, dll tetapi ada pula yang tidak mau menerima kelahiran sang juruselamat itu seperti raja Herodes.

Setelah Yesus di lahirkan, maka orang-orang Majus datang mencari Yesus ke Yerusalem tepatnya ke istana raja Herodes. Mendengar itu, maka Herodes dan seluruh Yerusalem terkejut sehingga Herodes ingin membunuh Anak itu. Herodes ingin membunuh anak itu karena kekuatirannya bahwa ia akan mendapat saingan dalam hal pemerintahan. George Eldon Ladd mengatakan, "Herodes Agung memandang nubuat ini dalam terminologi kekuasaan politik karena ia mengkwatirkan tahtanya sendiri. Ia tidak akan membiarkan saingan apapun, itulah sebabnya ia berusaha membinasakan Yesus."3

Allah dalam kemahakuasaanNya, mengetahui niat jahat dari Herodes ini sehingga Ia menampakkan diri dalam mimpi kepada Yusuf supaya mereka menyingkir ke Mesir. J.J. de Heer mengatakan,

Sangatlah penting bahwa Yesus aman di Mesir. Di sini kita melihat betapa "dramatis" sejarah Kerajaan Allah: pada waktu Allah menjelma menjadi manusia, langsung ada perang mati-matian di antara Herodes, raja duniawi, yang mau mempertahankan kemuliaannya sendiri, dan Yesus, Raja yang benar atas seluruh dunia. Tetapi Tuhanlah yang paling berkuasa, Ia melindungi Yesus terhadap Herodes, supaya rencana Tuhan tentang pekerjaan Yesus dapat terlaksana di kemudian hari. Itu arti "teologis" dari pelarian ke Mesir.4

Yesus diungsikan ke Mesir adalah salah satu bukti bagaimana Allah melindungi bayi itu dan umatNya. Alkitab Penuntun Hidup berkelimpahan mengatakan, "Usaha Herodes untuk membunuh Yesus dan cara Allah melindungi sang bayi menyatakan beberapa kebenaran tentang cara yang dipakai-Nya untuk menuntun dan melindungi umat-Nya."5

Ayat 13 mengatakan "Setelah orang-orang majus itu berangkat, nampaklah malaikat Tuhan kepada Yusuf dalam mimpi dan berkata: "Bangunlah, ambillah Anak itu serta ibu-Nya, larilah ke Mesir dan tinggallah di sana sampai Aku berfirman kepadamu, karena Herodes akan mencari Anak itu untuk membunuh

2 Marsi Bombongan Rantesalu and calvin sholla rupa, EKSPOSISI FILIPI 2:1-11, preprint (AgriXiv, October 24, 2019), accessed January 21, 2020, https://osf.io/xptck.

3 George Eldon Ladd, Teologi Perjanjian Baru, 1 (Bandung: Kalam Hidup, 2002).

4 J.J.de Heer, Tafsiran Alkitab. Injil Matius Pasal 1-22 (Jakarta: BPK Gunung Mulia, 2008).

5 Donald C. Stamps, Alkitab Penuntun Hidup Berkelimpahan (Malang: Gandum Mas, 2004). 
Dia." Allah berfirman kepada Yusuf supaya mereka menyingkir ke Mesir dengan tujuan untuk terhindar dari rencana jahat Herodes yaitu membunuh bayi tersebut. Kemudian ayat 15 a mengatakan, "dan tinggal di sana hingga Herodes mati." Ayat 15 a ini dengan jelas menyatakan bahwa Yesus dan orang tuanya berada di Mesir pada saat Herodes masih hidup dan setelah Herodes mati maka mereka meninggalkan Mesir.

Herodes sebagai Raja yang mempunyai kekuasaan pada saat itu tidak bisa membunuh Yesus karena Allah menyertai mereka (Yusuf, Maria dan Yesus) sebagai bukti bahwa tidak seorangpun yang dapat menggagalkan rencana Allah, siapapun dia termasuk penguasa.

\section{Pengungsian Ke Mesir adalah Hal yang Normal dan Wajar}

Mesir adalah tempat yang aman bagi orang Israel jika mereka mendapat kesulitan. Sebelum peristiwa Yesus diungsikan ke Mesir, jauh sebelumnya sering terjadi bahwa jika orang Israel mengalami kesulitan maka mereka lari ke Mesir sehingga banyak orang yahudi yang menjadi penduduk di Mesir. Pada saat orang tua Yesus membawaNya ke Mesir, mereka tidak merasa sebagai orang asing karena di Mesir juga terdapat banyak orang Yahudi. William Barclay mengatakan, pengungsian ke Mesir itu merupakan hal yang normal dan wajar. Di dalam jamanjaman dan abad-abad yang penuh dengan kesukaran, khususnya sebelum Yesus datang, kalau ada penguasa melakukan hal-hal yang menyulitkan kehidupan orang Yahudi, maka orang-orang Yahudi itu mengungsi ke Mesir. Akibatnya ialah bahwa di setiap kota di Mesir terdapatlah koloni-koloni orang Yahudi. Bahkan di kota Alexandria terdapat lebih dari satu juta orang Yahudi sehingga sebagian wilayah kota tersebut diserahkan kepada orang-orang Yahudi itu. Jadi di dalam waktu yang sangat sulit itu Yusuf sebenarnya melakukan apa yang sering dilakukan oleh orangorang Yahudi. Dan ketika Yusuf dan Maria sampai ke Mesir mereka tentu akan bertemu dengan orang-orang Yahudi juga, sehingga mereka tidak akan merasa terlalu asing. Di Mesir terdapat banyak orang Yahudi yang melakukan pelarian pengungsian seperti itu.6

Dengan mengungsikan Yesus ke Mesir, bukanlah hal yang baru bagi orang Yahudi, melainkan hal ini sudah sering dilakukan oleh orang-orang Yahudi jauh sebelum Yesus jika mereka mengalami kesulitan di daerah mereka.

6 William Barclay, Pemahaman Alkitab Setiap Hari. Injil Matius Pasal 1-10 (Jakarta: BPK Gunung Mulia, n.d.). 


\section{Maksud dari Matius Mengutip Hosea 11:1}

Beberapa pendapat dari penafsir memberikan penjelasan tentang ayat ini yaitu ungkapan Matius dalam Matius 2:15 yang mengutip Hosea 11:1.

J.J. de Heer menjelaskan bahwa Matius mengutip ayat ini karena Matius menganggap Yesus sebagai intisari dari Israel.

Matius dengan sendirinya tahu bahwa dalam kitab Hosea dengan "anak Tuhan yang dipanggil dari Mesir itu" bangsa Israellah yang dimaksudkan. Tetapi ia menganggap Yesus sebagai intisari dari bangsa Israel. Proff. Dr. O. Cullmann, ahli Perjanjian Baru yang terkenal pernah mengatakan bahwa dalam Alkitab kita menemukan suatu "reduksi", artinya penyempitan. Sebenarnya semua bangsa harus melayani Tuhan, tetapi karena mereka gagal maka Allah memilih bangsa Israel. Waktu bangsa Israel gagal juga, nabi-nabi mulai berkata tentang suatu "sisa" dari bangsa Israel, yang akan bertobat kepada Tuhan. Tetapi pada akhirnya hal itu "dipersempit" kepada satu orang saja: Yesus Kristus menjadi orang satu-satunya yang melayani Tuhan dengan sempurna. Dengan jalan itu Tuhan Yesus menjadi "intisari" dari bangsa Israel, sebab itu ayat-ayat dalam Perjanjian Lama yang berbicara tentang Israel dapat dikenakan oleh Matius di tempat ini.7

William Barclay memberikan penjelasan tentang ayat itu sebagai berikut: pertama, kitipan Matius dari Hosea pasal 11:1 itu aslinya tidak mempunyai haubungan sama sekali dengan penyingkiran Yesus ke Mesir. Ucapan itu tidak lebih dari suatu ucapan sederhana tentang bagaimana Allah melepaskan umat Israel dari perhambaan dan penindasan di tanah mesir. Kedua, adalah cara khas dari Matius yang mengutip Perjanjian Lama walaupun hal itu tidak pernah dimaksudkan untuk menubuatkan Yesus. Matius mengetahui bahwa cara satusatunya yang bisa dipakai untuk meyakinkan orang Yahudi, bahwa Yesus adalah Mesias yang dijanjikan oleh Allah, adalah membuktikannya bahwa Yesus adalah pemenuhan nubuatan PL. Dan di dalam usahanya yang penuh semangat untuk melakukan hal itu, ia menemukan banyak nubuat di dalam PL yang dianggapnya menunjuk kepada Yesus, walaupun aslinya tidaklah demikian. Matius memakai cara ini untuk menyapa orang Yahudi sebagai tujuan dari penulisan Injilnya dan nampaknya cara ini berhasil, dan itulah yang dimaksudkan oleh Matius ketika ia menulis Injilnya.8 Hal yang kedua dari Barclay ini juga sama dengan apa yang dikatakan oleh Henry, "Dari semua pemberita Injil, Matius paling banyak mencatat penggenapan Kitab Suci yang menyangkut kristus, sebab Injilnyalah yang pertamatama diterbitkan di antara orang-orang Yahudi, yang dengan demikian semakin

7 Heer, Tafsiran Alkitab. Injil Matius Pasal 1-22, 29-30.

8 Barclay, Pemahaman Alkitab Setiap Hari. Injil Matius Pasal 1-10, 56-57. 
menambah kekuatan dan kemasyuran Injil itu."9 Henry memberikan penjelasan lebih lanjut bahwa Kitab Suci tidak boleh ditafsirkan secara pribadi, melainkan harus memberikan keleluasaan penuh pada penerapannya. Mereka yang membaca ayat ini (dalam PL seperti dalam Hosea 11:1) jangan hanya berpikir untuk menengok ke belakang saja, tetapi lihatlah ke depan juga, karena apa yang pernah ada akan ada lagi (Pkh. 1:9), dan seperti yang telah dijelaskan sebelumnya bahwa bukan hal yang baru lagi kalau anak-anak Allah berada di Mesir pada saat mereka mengalami kesusahan di negerinya.10

Berdasarkan pendapat di atas, maka dapat dikatakan bahwa maksud dari Matius mengutip Hosea 11:1 adalah karena pertama, Matius melihat Yesus sebagai intisari dari Israel; kedua, adalah cara dari Matius untuk menyapa orang yahudi dan meyakinkan mereka bahwa Yesus adalah sebagai penggenapan dari nubuatan dalam Perjanjian Lama; ketiga, dalam menafsirkan Alkitab, penafsir harus memberikan keleluasaan penuh bagi penerapan ayat-ayat yang ada dalam kitab suci.

\section{Penafsiran Midrash}

Penulisan Alkitab tidak bisa dipisahkan dari kehidupan orang Yahudi yang memegang peran penting pada saat itu.11 Dengan demikian maka penulisan dan penafsiran yang dikenal pada masa itu juga turut mempengaruhi penulisan Alkitab. Kutipan Matius dari Hosea 11:1 ini tidak terlepas dari penafsiran Midras ini. Aapakah "midras" itu?

Menurut pendekatan "PaRDeS" untuk eksegesis, tafsiran naskah Alkitab dalam Yudaisme dilakukan melalui peshat (makna harafiah; arti kata sebenarnya: "sederhana" atau "jelas"), remez (makna mendalam; arti kata sebenarnya: "pertanda"), derash (makna perbandingan, dari kata Ibrani darash - "menanyakan" atau "mencari") dan sod (makna atau filsafat tersembunyi, arti kata sebenarnya: "rahasia" atau "misteri"). Midras agak berpusat kepada remez tetapi umumnya derash (Sejumlah pemikir membagi "PaRDeS" menjadi peshat, remez, din (hukum) dan sod. Dalam pengertian ini, "midras hagada" berkatian dengan remez sedangkan "midras halakha" berhubungan dengan din).12

9 Matthew Henry, Tafsiran Matthew Henry. Injil Matius 1-14 (Surabaya: Momentum, 2007). 10 Ibid., 44.

11 Ezra Tari and Marsi Rantesalu, Bahan Ajar Pengetahuan Perjanjian Baru, preprint (AgriXiv, June 18, 2019), accessed January 21, 2020, https://osf.io/bu3gy.

12 “Midrash,” n.d., accessed December 27, 2019, http://id.wikipedia.org/wiki/Midras. 
Dari penjelasan di atas, maka midras adalah tafsiran naskah Alkitab dalam Yudaisme dengan pengertian bahwa penafsiran tersebut memiliki makna yang sangat mendalam atau penafsiran midras adalah penafsiran perbandingan atau menghubungan sesuatu dengan hal lain.

Dalam penafsiran midras, sering ditemukan bahwa kalimat-kalimat tersebut nampaknya yidak ada kaitannya sama sekali tetapi kemudian dituliskan atau dikutip dalam kitab lain sesuai dengan keinginan penulisnya.

Banyak midras dimulai dengan kalimat-kalimat yang nampaknya tidak berhubungan dari Kitab Mazmur, Kitab Amsal atau Kitab nabi-nabi. Kalimat ini kemudian ternyata secara metafora mencerminkan isi penafsiran rabinik. Strategi ini khususnya dibagai dalam sebuah sub-genre midras yang dikenal sebagai "petikhta." Beberapa diskusi Midras bersifat sangat metaforis, dan banyak pengarang Yahudi menekankan bahwa hal itu tidak untuk diterima secara harafiah. Sebenarnya, sumber midras lain kadang menjadi kunci suatu diskusi esoterik. Pengarangpengarang selanjutnya menganggap bahwa hal ini dilakukan untuk membuat materinya tidak mudah dicapai oleh pembaca biasa dan mencegah penyalahgunaan oleh mereka yang tidak senang.13

Dengan demikian maka midras adalah pola penulisan dan penafsiran yang sebenarnya tidak memiliki hubungan satu dengan yang lain tetapi penulis seolaholah mengatakan bahwa ada hubungan dengan tujuan agar tulisan tersebut tidak mudah dicapai oleh pembaca biasa. Jerry Rumahlatu mengatakan "Penafsiran midrash adalah inti penafsiran yang dilakukan oleh rabi (yang kemudian dikenal dengan orang Farisi). Jika dilihat ke belakang midrash berupaya menembus ke lapisan lebih dalam dari Alkitab. Penyelidikan ini melihat dari berbagai sudut dan menemukan makna yang tidak segera terbaca (yang penulis sebut sebagai makna tersirat)."14

Penafsiran midrash adalah jenis penafsiran biblis rabbinik yang dikenal dengan nama midrash bekerja dengan cara serupa. Para Rabbi memparktikkan sebuah prinsip yang mereka sebut gezerah shawah, yang secara harafiaf berarti "injungsi serupa". Cara penarikan kesimpulan dengan analogi semacam ini berarti bahwa ketika kata-kata dengan makna yang mirip atau sama muncul di dua bagian tertentu di teks Hukum - tidak peduli betapa keduanya sebenarnya berbeda memiliki penerapan yang sama.15

13 Ibid.

14 Jerry Rumahlatu, Hermeneutika Sepanjang Masa (Cipta Varia Sarana, 2011).

15 “Naskah Laut Mati, 'Penafsiran Midrash,'” n.d., accessed January 3, 2020, di http://books.google.co.id/books?id=VPNgZNuLkqUC\&pg=PA478\&lpg=PA478\&dq=penafsiran+midras 
Dengan melihat beberapa pendapat di atas, maka sebenarnya bahwa dalam Injil Matius 2:15 di mana Matius mengutip dari Hosea 11:1 itu sangat dipengaruhi oleh penafsiran midrash yaitu penulis sebuah buku atau kitab mengutip langsung dari buku atau kitab lain tanpa melihat hubungannya satu dengan yang lain. Pengutipan tersebut terjadi karena keinginan dari penulis itu sendiri.

\section{Kesimpulan}

Berdasarkan pembahasan dari Bab sebelumnya, maka kesimpulan dari makalah ini adalah sebagai berikut:

Pertama, tidak seorangpun yang dapat menggagalkan rencana Allah. Allah akan menyatakan perlindungan kepada orang-orang yang dikehendaki-Nya.

Kedua, pengungsian ke Mesir adalah hal yang normal dan wajar seperti yang telah dilakukan oleh orang Yahudi lainnya jauh sebelum Yesus dan orang tuanya menyingkir ke Mesir.

Ketiga, maksud dari Matius mengutip Hosea 11:1 adalah pertama, Matius melihat Yesus sebagai intisari dari Israel; kedua, adalah cara dari Matius untuk menyapa orang yahudi dan meyakinkan mereka bahwa Yesus adalah sebagai penggenapan dari nubuatan dalam Perjanjian Lama; ketiga, dalam menafsirkan Alkitab, penafsir harus memberikan keleluasaan penuh bagi penerapan ayat-ayat yang ada dalam kitab suci. tersebut.

keempat, penafsiran midras digunakan oleh Matius dalam pengutipan

\section{Daftar Pustaka}

Barclay, William. Pemahaman Alkitab Setiap Hari. Injil Matius Pasal 1-10. Jakarta: BPK Gunung Mulia, n.d.

Heer, J.J.de. Tafsiran Alkitab. Injil Matius Pasal 1-22. Jakarta: BPK Gunung Mulia, 2008.

Henry, Matthew. Tafsiran Matthew Henry. Injil Matius 1-14. Surabaya: Momentum, 2007.

Ladd, George Eldon. Teologi Perjanjian Baru. 1. Bandung: Kalam Hidup, 2002.

h\&source=bl\&ots=A0xBAugcyn\&sig=71vzwzO1MqKzgg98AVqhVMkxMcM\&hl=id\&sa=X\&ei=J7MsUfzu G82NrgfdkYDYDw\&redir_esc=y\#v=onepage\&q=penafsiran $\% 20$ midrash \&f=false. 
Rantesalu, Marsi Bombongan. DOKTRIN KERAJAAN SERIBU TAHUN

BERDASARKAN KITAB WAHYU. Preprint. AgriXiv, October 14, 2019.

Accessed January 21, 2020. https:/ / osf.io/cpvjr.

Rantesalu, Marsi Bombongan, and calvin sholla rupa. EKSPOSISI FILIPI 2:1-11.

Preprint. AgriXiv, October 24, 2019. Accessed January 21, 2020.

https://osf.io/xptck.

Rumahlatu, Jerry. Hermeneutika Sepanjang Masa. Cipta Varia Sarana, 2011.

Stamps, Donald C. Alkitab Penuntun Hidup Berkelimpahan. Malang: Gandum Mas, 2004.

Tari, Ezra, and Marsi Rantesalu. Bahan Ajar Pengetahuan Perjanjian Baru. Preprint. AgriXiv, June 18, 2019. Accessed January 21, 2020. https://osf.io/bu3gy.

“Midrash,” n.d. Accessed December 27, 2019. http://id.wikipedia.org/wiki/Midras.

“Naskah Laut Mati, 'Penafsiran Midrash,'” n.d. Accessed January 3, 2020. di http://books.google.co.id/books?id=VPNgZNuLkqUC\&pg=PA478\&lpg=P A478\&dq=penafsiran + midrash\&source $=$ bl\&ots $=$ A0xBAugcyn\&sig $=71 \mathrm{vzwz}$ O1MqKzgg98AVqhVMkxMcM\&hl=id\&sa=X\&ei=J7MsUfzuG82NrgfdkYDY Dw\&redir_esc $=y \# v=$ onepage $\& q=$ penafsiran $\% 20$ midrash $\& f=$ false . 